\title{
Cabinet shifts unlikely to help South African universities
}

Cape Town. University officials see the appointment next month of the fourth minister of national education since September 1989 as an unfortunate sign that the government of $\mathrm{Mr} \mathrm{F}$. W. de Klerk remains unwilling to make the type of reforms needed to ensure that the country has enough scientifically trained workers.

Piet Marais, who as the present Minister of Education and Culture oversees the country's white education system, will be responsible in his new post for funding university research and the research councils as well as for overall educational policy. But observers say that he is no more likely to deal aggressively with the problems facing the country's education system than was his predecessor, Louis Pienaar. Experts estimate that the country must train 125,000 new teachers and improve the skills of 84,000 others by the turn of the century while integrating the country's racially structured education departments into one system.
"If the universities are to do anything other than muddle along, there has to be bold intervention", says Hugh Amoore, registrar of the University of Cape Town.

The universities themselves have been unwilling to come to grips with the impact of the twofold expansion in student numbers of the past decade. Graduate numbers in science and engineering have dropped from 17 per cent of the total to only 13 per cent, and those in medicine from 11 per cent to 7 per cent, reflecting the fact that most African students do not study mathematics and science at school for lack of teachers.

Although there is consensus among government, the African National Council and the private sector that South Africa's manpower needs are not being met by its current supply of graduates, none of the groups has endorsed a proposed solution to the problem that would subsidize fixed numbers of places in each faculty at each university.

Michael Cherry

\section{Botswana needs science help to save plant and animal species}

London. Botswana faces a situation that is common to many developing countries not enough scientific talent. But a group of visiting environmental scientists, believing that the country's need to protect and preserve its plant and animal resources must take precedence over the government's wish to develop its own expertise, are urging Botswana to hire outsiders as a temporary solution to the problem.

In a preliminary report of their findings, members of the mission to the southern African nation said last week that the dearth of professionally trained wildlife scientists and managers is responsible for a lack of environmental and wildife data on the country. This could hinder implementation of the government's ambitious National Conservation Strategy and also weaken its ability to respond to those who have criticized its record on conservation. The fact-finding mission was commissioned to investigate just such criticisms.

"The immediate need is such that it is not feasible to wait until the current Batswana junior echelons have built up the necessary experience," said Andrea Pfister, an ecologist with the Conservation Foundation in London, who was part of the mission. "The country should request and allow the donor community to provide and/or finance such executive cadres, not on short-term con- tracts but with a measure of continuity that will ensure that their successors inherit a well-functioning administration, rather than deskfuls of overdue projects."

This approach would also help to nurture indigenous talent by producing a range of young researchers with formal degrees, preferably based on research work done in Botswana. It would also provide them with enough work experience to give them confidence and authority in making decisions.

The fact-finding mission was prompted by internal and international criticisms of the country's conservation and environmental policies. They grow out of allegations by the film-maker Rick Lomba, a resident of neighbouring South Africa, that the government has colluded in the destruction of the Botswana's unique environment, which includes an extensive wetland around the Okavango delta, and has failed to protect the country's wildlife.

The mission concluded that Botswana's national conservation strategy is "by any standards a remarkable and impressive document. Few countries can boast such a strategy and the consultation process which produced it." But the real test of the government's commitment, it said, rests on the implementation of that strategy - and the talent to carry it out.

Ian Mundell

\section{IN BRIEF}

Washington. Prompted by Congress to think small, the US National Aeronautics and Space Administration (NASA) has drafted plans for a series of cheap, quick planetary probes for later in the decade. Each mission would cost less than $\$ 150$ million and be launched within three years of its initiation. In a report submitted to Congress earlier this month, NASA said that the new approach would make space accessible to more investigators and institutions and fill the gaps between the larger missions already planned.

Modelled on the existing Explorer and Earth Probes projects, the new Discovery programme would include a proposal to place a total of about 16 small automated surface stations on Mars to study the planet's geology and weather. The European Space Agency is studying a similar proposal, NASA said.

Washington. Seymour Cray, the inventor of the supercomputer, has finally agreed to consider what most other

supercomputer manufacturers already believe to be the future of the field. Cray, the chairman of the Cray Computer Corporation, told an annual stockholders' meeting last week that he was "having discussions" with makers of massively parallel supercomputers about a joint marketing arrangement. Such an agreement would mark Cray's first radical departure from the design he pioneered more than 20 years ago. Massively parallel machines achieve their speed by combining hundreds or thousands of simple and cheap processors, in contrast to the small number of very fast and expensive processors in Cray's designs.

Cray's change of heart is partly due to his company's shaky financial position: its unfinished prototypes do not work properly and its only customer dropped out last year. Even so, a move into massively parallel computers does not guarantee financial success. Cray Research Inc., the company that Cray founded in 1972 and left in 1989 to form Cray Computer, recently announced its own shift into the fieid (see Nature 356, 95; 1992). But last week Cray Research announced that increased competition and ebbing demand are expected to lower its earnings by $10-$ 20 per cent compared with last year. CA

Washington. After months of speculation that Nobel Laureate David Baltimore would be leaving the Rockefeller University, Baltimore confirmed early this week that he will depart, but not until 1994. Once the Massachusetts Institute of Technology finishes its new biology building, Baltimore will return to continue his AIDS research at the university where he was a professor and founding director of the Whitehead Institute until 1990. Until stepping down to take a faculty position last December in the wake of a divisive scientific misconduct investigation, Baltimore was the president of Rockefeller. 